\begin{tabular}{ccc}
\hline & $\begin{array}{c}\text { International Journal of Health Services } \\
\text { Research and Policy } \\
\text { www.dergipark.org.tr/ijhsrp }\end{array}$ \\
INTERNATIONAL \\
ENGINEERING \\
SCIENCE AND \\
EDUCATION GROUP
\end{tabular}

Research Article

\title{
READING ROUTINES OF COMMUNITY HEALTH EXECUTIVES UPON MANAGERIAL TOPICS, WITHIN THE CONTEXT OF HEALTH TRANSFORMATION PROGRAM (HTP) IN THE TURKEY; DIYARBAKIR CASE
}

\author{
Mehmet Emin Kurt ${ }^{1 *}$ (D) Ali Ceylan ${ }^{2}$ (D) \\ ${ }^{1}$ Dicle University Faculty of Economics and Administrative Sciences, Department of Health Management, \\ Diyarbakır, Turkey, \\ ${ }^{2}$ Dicle University Faculty of Medicine, Department of Public Health, Diyarbakır, Turkey \\ * Corresponding author; mekurt1@ @otmail.com
}

\begin{abstract}
Due to the ever-changing, developing, and complex structures of health institutions, the need to manage their administrations via professional managers arised by the end of the 1800s in the world, mainly in the USA and Europe, and such a need has been continuously emerging in our country since the 1950s. Concerning those current professional health managers, who serve in a rapidly evolving and changing health sector, following periodicals, books, and articles on general or health management should be among the sine qua non for the development and change of such professional health management. Together with the Health Transformation Program (HTP) that has been implemented in Turkey since 2003, despite the adoption of the understanding that predominantly professional healthcare managers should be assigned in the management of health institutions, there are still many managers operating in the sector, who are not adequately educated. The aim of this study is to determine the prevalence of those managers of the public health administrators in Diyarbakir, reading articles, books, and periodicals on general-health management for their development. The study is a descriptive study, involving 165 healthcare managers, which mainly have been serving in 3 public health institutions (Provincial General Secretariat to Association of Public Hospitals, Provincial Directorate of Community Healthcare, Provincial Directorate of Health and its affiliated units) in Diyarbakir province prior to November 25th, 2017. 80.7\% of the managers did not have a master's degree in health-general management education. It was determined that health administrators have a low reading habit of reading books, articles, and periodicals and reading habits do not differ significantly according to their basic professions ( $p>0.05$. In the case of Diyarbakır, it is obviously seen that health-care administrators are urgently required to undertake bachelor, masters, Ph.D. programs on general health management.
\end{abstract}

Keywords: Health Management, Health Transformation Program (HTP), Periodical Reading, Internet Use, Reading on Health Topics.

Received: September 15, 2020

Accepted: November 24, 2020 


\section{Introduction}

It is defined in many studies that, the most meaningful issue from the viewpoint of Community Health is, to make scientific information provided in order to give medical information and to produce the desired behaviors for the patient, meaningful to the patient in order to ensure it to be understood and interpreted by the patient. Because individuals encounter too much complex information and treatment processes while receiving service in the health sector. This situation is perceived as a deep, complex, and rapidly changing area that requires patients to be able to define their own health situation, to have information regarding their diseases, to make appropriate decisions about their health, and to know how to benefit from the existing healthcare system. The limited level of health literacy adversely affects the diagnosis and treatment of the disease, on the other hand, it increases the prevalence of hospitalization and prolongs the hospitalization period [1].

The HTP (Health Transformation Program), introduced regarding our country's health system refers to the radical changes that have been made in our country's health system from 2003 to the present. It is the name of reform, which was first verbalised and discussed between 1991 and 1993, but so-called as after 2003, together with Justice and Development Party (AK Parti) governments. The components that make up HTP so important is the privatization of health institutions and service providers through the entire system, by providing centralized management and control at the first stage of transformation [2].

The reason why the HTP was preferred to be implemented throughout the country was because of the ongoing failures in the previous system. Some of the reasons that force the Government for a HTP can be listed as, physicians who demand illegal money to their own accounts for the surgical operation, while they benefit from public facilities, doctors referring their patients to their private practice, patients with insufficient economical conditions who are held in pledge at the hospital, until their medical bills are paid in full by themselves or their relatives, prolonged referral and bureaucratic paper processing of patients, long queues at hospitals due to excessive accumulation in hospital ambulatory care services, problems in procurement of patients' drugs, problems in hospitals providing drugs for their inpatients, the inability of the patients with different social security institutions to access the health services adequately, the inability of citizens to provide access to health services in a manner that is equitable and fair to justice, and the chronic and subsequent patient's dissatisfaction [3].

HTP consists of a total of eight components that try to shape the health sector with all dimensions. Among these 8 components, we can mention; the reorganization of the central and provincial administrative structure of the Ministry of Health, strengthening its planning, leadership and supervisory role, a general health insurance system covering everyone, structuring healthcare service provision in a way that will provide access to the whole country, high level of knowledge and skill throughout the sector, e-health system coordinated with adequate technological information systems; quality and accreditation of educational and scientific institutions to support the system, and institutional restructuring regarding the management of medicine and medical suppliers [4].

The most important elements within the scope of HTP are; Family Practices, General Health Insurance, and Self-Governing Hospitals. These three elements form an integral whole, complementing each other. One of the most important goals of the HTP is to enable citizens to benefit from healthcare services more efficiently and equally. Regarding the successful process of HTP; acting within a quality management model, restructuring and gathering the budget of various health institutions with different 
structures under a single roof, "General Health Insurance" (GSS) and the means by which the health service is delivered to the citizens (access to health services) are the issues of great importance.

In order to achieve the success of HTP, it is essential to keep the employee motivation high and that to provide services via a well-trained and skilled workforce. It will be inevitable to increase the quality and efficiency in the provision of healthcare services by creating an appropriate environment for personnel planning and having them participated in health management [5].

It is essential for the sustainability of HTP, to meet the need for people who have a comprehensive knowledge of health-related subjects, and who have received the necessary training. It will be ensured to provide high-quality healthcare services thanks to people who have received health education at national standards in addition to the graduates of the departments of medicine, nursing, and health services vocational high schools. In order for the HTP to be successful, it is necessary to create a very different managerial approach rather than the previous ones. While a physician-based managerial approach has been adopted in health care institutions up to present, a new approach via educated, disciplined, competent, experienced, knowledgeable managers well trained on health policies and health-related economics will be preferred, and this will bring success [6].

As stated above, the necessity of the managers having the right practicum in the field of health management has been expressed by the Health Minister of the time that, in order to achieve the success of the HTP. This requires health managers to have Literacy on Health Information on health and managerial subjects throughout their professional life. The complex structure of the health sector, like any other developing and changing dynamic structure, demonstrates that a healthcare manager needs to constantly improve him/herself.

If we consider the matter from a different point of view, it is important that health managers should be professionalized in their field of management; because in almost all countries of the world, administration regarding not only the health sector but all other institutions and organizations, are handled by professionals specialized in the related field. Particularly in western countries, the health sector is managed by professional managers. In our age, it is a known fact that knowledge is produced instantly, information is respectively easier to reach and the only way to achieve success in all sectors is professional management.

The health care manager is an organizer who ensures that health services are presented and delivered in an effective manner by employees with different expertise in accordance with the presentation objectives. It is a targeted situation that the manager, based on his/her ability to offer solutions to the problems that may be encountered, social characteristics and the intellectual knowledge level, is aware of his/her individual characteristics, possible deficiencies and self analyse him/herself within this direction [7].

If we are to define health managers within the scope of their theoretical knowledge and their professionalization in accordance with educational criteria, and in terms of managerial concepts; the manager can be described as "the person responsible for the implementation and performance of the information" [8].

Despite the HTP in our country, the role of hospital management is carried out by physicians or nurses who have not received adequate professional health or managerial education, as an additional role besides their main occupations. However, in the report published in Copenhagen in 1996 by the World Health Organization, it is emphasized that, especially an increase in the number of people who have undergone in-depth training and the placement of the health information system in accordance with 
the reform to be made, would bring this success within the scope of implementation of Health Reforms [9].

Hospital management is a complex task and it is difficult to carry out this without obtaining vocational training on this subject. Health institutions have characteristics that make them different from other structures and enterprises. Health services should be provided to everyone, anytime, anywhere, efficiently, economically, quality, effective, equal, continuous, and accessible. For these reasons, the health sector should be managed by professional managers. Regardless of his/her position, it is an obligation for managers to be equipped with modern management and business knowledge and skills. Moreover, the management of health institutions is much more complex than the management of any other economic enterprise. It is not a business that can be accomplished solely with medical education or nursing to manage a business where on the one hand floors are constantly cleaned, and procurement of food services is carried out by tender, and open heart operations are performed on the other. Hospital management covers human resources, planning, and management of a wide range of services such as hotel services, operating room services, filing, and archive services, hotel services, catering and cleaning services, pharmacy services, as well as hotel services, health services It is not possible to say that physicians or nurses who have not been trained in medical schools or nursing schools will be successful in these fields [8].

In our country, especially following the implementation of HTP, the fact that family physicians have not yet been perceived as the first step in health care by the patients (the problem of lacking adequate health literacy or the fact that this information has not been expressed enough to the citizens by the subject of the issue), and that the referral system has not been introduced yet, causes inappropriate use of public hospitals and in particular emergency services of privately owned health institutions (Crowding) and imposes additional burdens (financial sustainability) to the health system.

The question that comes to mind is that; while the importance of health literacy for those who demand healthcare service, is emphasized as the most important issue within the context of providing better quality healthcare services in many academic studies, the extent to which people in charge of the management of the health sector pay attention to their own health literacy, despite the complexity and diversity of the service they offer, the situation and requirements that we can define as Literacy on Health Information, still stand out as an overlooked concept.

In the interest of the success of health systems as a product of countries' health policies, or if we want to define the matter specifically for our own country, in order to achieve a successful result regarding HTP, which has been implemented for the last 16 years, determining the amount of time spent by existing healthcare providers on their Literacy on Health Information, should be considered as one of the important parameters that will increase the likelihood of success of the transformation.

Prior to November 25th, 2017, there were 3 headed, 3 official health institutions operating in the provinces, namely the Provincial General Secretariat to Association of Public Hospitals and its affiliated units, Provincial Directorate of Community Healthcare and its affiliated units, Provincial Directorate of Health and its affiliated units. This managerial practice has been amended as of the date mentioned. This situation tells us that the former managers of the health sector should inevitably be analyzed regarding their reading habits of articles, books, and periodicals on general-health management, and this concept is quite mandatory in order to develop the management skills and to achieve success throughout the new process. 
In a study, it was found out that the managers of provincial health structures formed after HTP have been the former administrators in the public health sector, that is, the professional health manager requirement for SDP is met via the people of managerial experience regardless of their health management profession. It is an important concept to emphasize that this situation could create obstacles to the dynamism, innovation, development, creative ideas, actions, and excitement, in short, the success of the system [10].

Health Sector Management includes different types of information to be manifested in a constant dynamism. Human resources management, quality, and accreditation, occupational health and safety, tender process, circulating capital, procurement, emergency management, and management of different service areas in the hospital, etc. Each of them requires very different levels of knowledge. It is expected for a health manager to continuously improve himself on different types of information in the health sector, through Literacy on Health Information, the fact that this requirement is not sufficiently fulfilled will make it difficult to succeed the sector and even the current HTP process in our country.

While it is a separate research topic whether the number of health managers with an MSc or doctorate degree in health or general management is at the desired level, revealing the necessary studies for Literacy on Health Information, together with HTP would evolve the process more quickly and successfully for our country. We argue that the introduction of this situation will contribute to the determination of whether the expected efficiency from the professional health administrators before November 2017 has been met. It should not be forgotten that the need for Literacy on Health Information, is a constant dynamism regarding successful health management. Because in the health sector, which is one of the constantly developing and transforming sectors of the age, follow-up information will contribute to the managerial skills of the manager.

Taking into consideration all these reasons mentioned above, the possibility of existing managers not having received adequate training on business, accounting, law, employee health and safety, human resources management, total quality management subjects, will lay the groundwork for emerging problems in the ongoing managerial processes. In this study, we will try to determine the effects of Literacy on Health Information on the managerial skills of existing public health managers, within the scope of the Diyarbakır case.

\section{Material and Method}

The study is a descriptive study, involving 165 healthcare managers, which mainly have been serving in 3 public health institutions (Provincial General Secretariat to Association of Public Hospitals and its affiliated units, Provincial Directorate of Community Healthcare and its affiliated units, Provincial Directorate of Health and its affiliated units) in Diyarbakır province prior to November 25th, 2017. The reason why that date has been selected is that by November 2017 Ministry of Health has amended the former provincial structure in a way to attribute the above-mentioned 3 provincial public health structure to the administration of the Provincial Directorate of Health, similar to the system before the HTP. However, this time, the provincial structures which had existed before November 2017, have been attributed to the Provincial Directorate of Health on a presidential basis. And after 2017, while the health management structure of the province was structured as a provincial health directorate, it was determined that the health managers before 2017 were also assigned as managers in the restructuring. Therefore, health information literacy needs to be examined separately in the new structure. 
It is aimed to reach all the healthcare managers of the city, a total of $135(81.8 \%)$ managers accepted to participate in the study. In order to collect data, a questionnaire of 11 questions was used which included questions on descriptive information of the healthcare managers, development of their managerial skills, and the determination of the effect of their literacy on their managerial skills. Data were collected through face-to-face interviews after obtaining their informed consent. The study has been approved by the Ethics Committee of Dicle University Medical Faculty. The data were evaluated in SPSS 21 (statistical package for social sciences) program, the frequency distributions were used in defining the descriptive characteristics of the health managers and Pearson Chi-Square was applied in the nominal variables where more than two groups were applied. Results were considered statistically significant in the case of a $95 \%$ confidence interval and where $\mathrm{p}<0.05$.

\subsection{Ethical Considerations}

Ethics committee approval was obtained from Dicle University Non-Interventional ethics committee for the study. (Certificate authorization number, 385 dated 23/10/15)

\section{Findings}

Descriptive information on the healthcare managers of Diyarbakir province participating in the study is given in Table 1 .

Table 1. Descriptive Information on the Healthcare Managers of Diyarbakir Province Participating in the Study

\begin{tabular}{|l|c|c|}
\hline Institutions and Affiliated Units Participating in the Study & n & \% \\
\hline General Secreteriatand Affiliated Hospitals & 96 & 64.4 \\
\hline Community Health Institutions and Affiliated Units & 19 & 12.8 \\
\hline Provincial Directorate of Health and Affiliated Units & 20 & 13,4 \\
\hline Roles of the Managers & $\mathbf{n}$ & $\mathbf{\%}$ \\
\hline Provincial Health Deputy Manager & 5 & 3.7 \\
\hline Chief Physician/Deputy Chief Physician & 28 & 20.8 \\
\hline Hospital Administrator(Health Care-Administrative-Financial-Health & 61 & 45.2 \\
\hline HospitalityManagersand Assistant Managers) & 3 & 2.2 \\
\hline Assistant Manager of Provincial Community Health & 10 & 7.4 \\
\hline Chief, Other & 3 & 2.2 \\
\hline Manager of Sub-Provincial Health & 3 & 2.2 \\
\hline Health Group Manager & 16 & 11.9 \\
\hline Branch Manager & 3 & 2.1 \\
\hline Financial, Administrative, Medical Managers & 3 & 2.2 \\
\hline Hospital Manager & $\mathbf{n}$ & $\mathbf{\%}$ \\
\hline Age & 43 & 31.9 \\
\hline 35 years old and below & 92 & 68.1 \\
\hline 36 years old and above & $\mathrm{n}$ & $\%$ \\
\hline Maritial Status & 117 & 86.7 \\
\hline Married & 18 & 13.3 \\
\hline Single & $\mathbf{n}$ & $\mathbf{\%}$ \\
\hline Gender & 34 & 25.2 \\
\hline Female & 101 & 74.8 \\
\hline Male & $\mathbf{1 3 5}$ & $\mathbf{1 0 0 . 0}$ \\
\hline Total & & \\
\hline
\end{tabular}

Evaluating the descriptive information of the healthcare managers of Diyarbakır province; in the context of the institution in which the participating managers operate, $64.4 \%$ is from the General 
Secretariat of the Public Hospitals Association of Diyarbakır Province, 12.8\% from the Provincial Directorate of the Community Health and $13.4 \%$ from the Provincial Health Directorate and its affiliated units. When the managers who participated in our study were evaluated in terms of their duties; it is seen that $20.8 \%$ of the participants are chief physicians or their assistants, $45.2 \%$ of them have consisted of the Hospital Administrators (Health Care-Administrative-Financial-Health Hospitality Managers and Assistant Managers). $68.1 \%$ of the managers were 36 years of age and above where $86.7 \%$ of the participants were married and $74,8 \%$ were male (Table 1 ).

Table 2. Professional and Managerial Education Information on the Healthcare Managers of Diyarbakir Province Participating in the Study

\begin{tabular}{|l|l|l|}
\hline Profession & n & \% \\
\hline Practitioner, Specialist & 49 & 36.3 \\
\hline Nurse-Health Officer & 47 & 34.8 \\
\hline Other & 39 & 28.9 \\
\hline Graduate Education on Health or General Management & $\mathbf{n}$ & $\boldsymbol{\%}$ \\
\hline None & 109 & 80.7 \\
\hline Graduate Level & 26 & 19.3 \\
\hline PhD & 0 & 0.0 \\
\hline Computer Literacy & $\mathbf{n}$ & $\boldsymbol{\%}$ \\
\hline Yes & 89 & 65.9 \\
\hline No & 46 & 34.1 \\
\hline I Read "Books" on Health or General Management & $\mathbf{n}$ & $\mathbf{\%}$ \\
\hline Yes & 46 & 34.1 \\
\hline No & 89 & 65.9 \\
\hline I Read "Articles" on Health or General Management & $\mathbf{n}$ & $\mathbf{\%}$ \\
\hline Yes & 47 & 34.8 \\
\hline No & 88 & 65.2 \\
\hline I Read "Periodicals" on Health or General Management & $\mathbf{n}$ & $\mathbf{\%}$ \\
\hline Yes & 24 & 17.8 \\
\hline No & 111 & 82.2 \\
\hline Total & 135 & 100.0 \\
\hline
\end{tabular}

Evaluating according to the professions of healthcare managers in Diyarbakır province, it was found out that $36.3 \%$ were physician managers, $80.7 \%$ of managers had not received bachelor's or Ph.D. degrees in general or health management. It was determined that only $19.3 \%$ of them had received a master's degree and only $65.9 \%$ of them were computer literate. Only $34.1 \%$ of the managers stated that they had been reading books on health or general management, $34.8 \%$ of them had been reading articles on health or general management and only $17.8 \%$ of them had been reading periodicals (Table 2). 
Table 3. Computer Literacy Range of Healthcare Managers of Diyarbakir Province Participating in the Study

\begin{tabular}{|c|c|c|c|c|c|c|c|c|c|c|}
\hline \multirow{2}{*}{$\begin{array}{c}\text { Computer } \\
\text { Literacy }\end{array}$} & \multicolumn{2}{|c|}{$\begin{array}{c}\text { Practitioner, } \\
\text { Specialist }\end{array}$} & \multicolumn{2}{|c|}{$\begin{array}{c}\text { Nurse, Health } \\
\text { Officer }\end{array}$} & \multicolumn{2}{|c|}{ Others } & \multicolumn{2}{|c|}{ Total } & \multirow{2}{*}{$\chi^{2}$} & p \\
\cline { 2 - 13 } & $\mathrm{n}$ & $\%$ & $\mathrm{n}$ & $\%$ & $\mathrm{n}$ & $\%$ & $\mathrm{n}$ & $\%$ & & \\
\hline Yes & 31 & 63.3 & 32 & 68.1 & 26 & 66.7 & 89 & 65.9 & 0.261 & 0,877 \\
\hline No & 18 & 36.7 & 15 & 31.9 & 13 & 33.3 & 46 & 34.1 & & \\
\hline Total & 49 & 100 & 47 & 100 & 39 & 100 & 135 & 100 & & \\
\hline
\end{tabular}

Evaluating the computer literacy of Healthcare Managers of Diyarbakir Province Participating in the Study; $34.1 \%$ of healthcare managers were found out not to use computers. According to Pearson chi-square analysis, no statistical significance was found in the comparison between groups of managers $\left(\chi^{2}=0.261 ; p>0.05\right)($ Table 3$)$.

Table 4. "Book" Reading habits on Health or General Management of Healthcare Managers of Diyarbakir Province Participating in the Study

\begin{tabular}{|c|c|c|c|c|c|c|c|c|c|c|}
\hline \multirow{2}{*}{$\begin{array}{l}\text { Reading "Books" } \\
\text { on health or } \\
\text { general } \\
\text { management }\end{array}$} & \multicolumn{2}{|c|}{$\begin{array}{c}\text { Practitioner, } \\
\text { Specialist }\end{array}$} & \multicolumn{2}{|c|}{$\begin{array}{c}\text { Nurse, Health } \\
\text { Officer }\end{array}$} & \multicolumn{2}{|c|}{ Others } & \multicolumn{2}{|c|}{ Total } & \multirow[t]{2}{*}{$\chi^{2}$} & \multirow[t]{2}{*}{$\mathbf{p}$} \\
\hline & $\mathrm{n}$ & $\%$ & $\mathrm{n}$ & $\%$ & $\mathrm{n}$ & $\%$ & $\mathrm{n}$ & $\%$ & & \\
\hline Yes & 17 & 34.7 & 17 & 36.2 & 12 & 30.8 & 46 & 4.1 & 0.290 & 0.865 \\
\hline No & 32 & 65.3 & 30 & 63.8 & 27 & 69.2 & 89 & 5.9 & & \\
\hline Total & 49 & 100 & 47 & 100 & 39 & 100 & 135 & 100 & & \\
\hline
\end{tabular}

Evaluating the "Book" Reading habits of Healthcare Managers of Diyarbakir Province Participating in the Study on Health or General Management; only $34.1 \%$ of the health care managers were found to read the book. According to Pearson chi-square analysis, no statistical significance was found in the comparison between groups of managers $\left(\chi^{2}=0.290 ; p>0.05\right)$ (Table 4).

Table 5. "Article" Reading habits on Health or General Management of Healthcare Managers of Diyarbakir Province Participating in the Study

\begin{tabular}{|c|c|c|c|c|c|c|c|c|c|c|}
\hline \multirow{2}{*}{$\begin{array}{l}\text { Reading articles } \\
\text { on health or } \\
\text { general } \\
\text { management }\end{array}$} & \multicolumn{2}{|c|}{$\begin{array}{l}\text { Practitioner, } \\
\text { Specialist }\end{array}$} & \multicolumn{2}{|c|}{$\begin{array}{l}\text { Nurse, Health } \\
\text { Officer }\end{array}$} & \multicolumn{2}{|c|}{ Others } & \multicolumn{2}{|c|}{ Total } & \multirow[t]{2}{*}{$\chi^{2}$} & \multirow[t]{2}{*}{$\mathbf{p}$} \\
\hline & $\mathrm{n}$ & $\%$ & $\mathrm{n}$ & $\%$ & $\mathrm{n}$ & $\%$ & $\mathrm{n}$ & $\%$ & & \\
\hline Yes & 18 & 36.7 & 17 & 36.2 & 12 & 30.8 & 47 & 34.8 & 0.399 & 0.819 \\
\hline No & 31 & 63.3 & 30 & 63.8 & 27 & 69.2 & 88 & 65.2 & & \\
\hline Total & 49 & 100 & 47 & 100 & 39 & 100 & 135 & 100 & & \\
\hline
\end{tabular}

Evaluating the "Article" Reading habits of Healthcare Managers of Diyarbakir Province Participating in the Study on Health or General Management; only $34.1 \%$ of the health care managers were found to read articles. According to Pearson chi-square analysis, no statistical significance was found in the comparison between groups of managers $\left(\chi^{2}=0.399 ; p>0.05\right)$ (Table 5). 
Table 6. "Periodicals" Reading habits on Health or General Management of Healthcare Managers of Diyarbakir Province Participating in the Study

\begin{tabular}{|c|c|c|c|c|c|c|c|c|c|c|}
\hline $\begin{array}{c}\text { Reading } \\
\text { "Periodicals" on } \\
\text { health or general } \\
\text { management }\end{array}$ & \multicolumn{2}{|c|}{$\begin{array}{c}\text { Practitioner, } \\
\text { Specialist }\end{array}$} & \multicolumn{2}{c|}{$\begin{array}{c}\text { Nurse, Health } \\
\text { Officer }\end{array}$} & \multicolumn{2}{|c|}{ Others } & \multicolumn{2}{|c|}{ Total } & $\chi^{2}$ & p \\
\hline & $\mathrm{n}$ & $\%$ & $\mathrm{n}$ & $\%$ & $\mathrm{n}$ & $\%$ & $\mathrm{n}$ & $\%$ & & \\
\hline Yes & 7 & 14.3 & 7 & 14.9 & 10 & 25.6 & 24 & 17.8 & 2,326 & 0.313 \\
\hline No & 42 & 85.7 & 40 & 85.1 & 29 & 74.4 & 111 & 82.2 & & \\
\hline Total & 49 & 100 & 47 & 100 & 39 & 100 & 135 & 100 & & \\
\hline
\end{tabular}

Evaluating the "Periodicals" Reading habits of Healthcare Managers of Diyarbakir Province Participating in the Study on Health or General Management; only 17,8\% of the health care managers were found to read periodicals. According to Pearson chi-square analysis, no statistical significance was found in the comparison between groups of managers $\left(\chi^{2}=2,326 ; p>0.05\right)$ (Table 6).

Table7. Post Graduate Education of Healthcare Managers of Diyarbakir Province Participating in the Study

\begin{tabular}{|c|c|c|c|c|c|c|c|c|c|c|}
\hline \multirow{2}{*}{$\begin{array}{l}\text { Having a post- } \\
\text { graduate degree? }\end{array}$} & \multicolumn{2}{|c|}{$\begin{array}{c}\text { Practitioner, } \\
\text { Specialist }\end{array}$} & \multicolumn{2}{|c|}{$\begin{array}{l}\text { Nurse, Health } \\
\text { Officer }\end{array}$} & \multicolumn{2}{|c|}{ Others } & \multicolumn{2}{|c|}{ Total } & \multirow[t]{2}{*}{$\chi^{2}$} & \multirow[t]{2}{*}{$\mathbf{p}$} \\
\hline & $\mathrm{n}$ & $\%$ & $\mathrm{n}$ & $\%$ & $\mathrm{n}$ & $\%$ & $\mathrm{n}$ & $\%$ & & \\
\hline None & 39 & 79.6 & 40 & 85.1 & 30 & 76.9 & 109 & 80.7 & 0.938 & 0.612 \\
\hline $\begin{array}{c}\text { Have Post } \\
\text { Graduate degree }\end{array}$ & 10 & 20.4 & 7 & 14.9 & 9 & 23.1 & 26 & 19.3 & & \\
\hline Total & 49 & 100 & 47 & 100 & 39 & 100 & 135 & 100 & & \\
\hline
\end{tabular}

Evaluating whether Healthcare Managers of Diyarbakir Province participating in the study have any postgraduate degree; it has been found out that only $19.3 \%$ of health managers received a postgraduate degree, but none of them had a Ph.D. degree. According to Pearson chi-square analysis, no statistical significance was found in the comparison between groups of managers $\left(\chi^{2}=0.983 ; p>0.05\right)$ (Table 7).

\section{Discussion}

Considering the public health sector, following the implementation of HTP, in the last 15 years when professional health management has been considered a sine qua non, Literacy on Health Information has always been discussed in accordance with those who demand health care service but Literacy on Health Information regarding health care providers has always been neglected.

In a study conducted by Öztürk et al. [11], 42\% of health managers were in the group above 40 years of age, $69.7 \%$ of them were male and $89.1 \%$ of them were married.

In our study, however, $68.1 \%$ of our healthcare managers were over 36 years of age, $74.8 \%$ of them were male and $86.7 \%$ of them were married. 
In our study, while the presence of young managers was low, the presence of male managers was found to be high. This situation made us think that despite the high number of women working in the health sector compared to other sectors of our country, women managers are still at a minimum.

Literacy on Health Information is important for healthcare researchers, academic education institutions, and organizations, healthcare professionals. Literacy on Health Information, ensures healthcare professionals to obtain continuously accurate, reliable, scientific, and up-to-date information on healthcare subjects. Literacy on Health Information also provides a more efficient, effective, and economic way of delivering clinical and community healthcare service. Also, Literacy on Health Information, allows health professionals, health educators, and health managers to improve themselves on how to better offer their services [12].

HTP implemented in our country has brought many adaptations regarding the sector. These adaptations affect both service providers and service recipients. Especially when the service providers are evaluated from the viewpoint of Literacy on Health Information, some important topics are considered as:

1. Service Providers-Service Recipients' Communication-Security,

2. Quality of Service Provided,

3. Easy Access to Services,

4. Time Constraints Regarding Health Sector Professionals,

5. Health Expenditures-Circulating Capital-Trust,

6. Healthcare Information Systems Technology,

7. Medical Information,

8. Security, Catering, Cleaning Services.

In a study, with the main theme of "Mobbing", conducted by Karsavuran S. [13], by the managers of all the hospitals of Ministry of Health in Ankara Province, It was stated that $28.4 \%$ of the managers had a master's degree without expressing whether the managers had a postgraduate degree on health or general management.

In our study, however, it was determined that $19.3 \%$ of the healthcare managers received a master's degree in general or health management. This ratio shows that the two provinces require the same levels of postgraduate education in management. Moreover, the fact that postgraduate education is so low reveals that professional health management should be emphasized in our country, especially in our province, in accordance with our health sector.

It is stated that only $34.1 \%$ of our health executives read "books" on health or general management and that the books read are limited to:

1- Health Services Marketing, Social Determinants of Health, Health Tourism,

2- İletişimce (Ministry of Health Publications),

3- Management of Healthcare Institutions,

4- Inpatient Institutions Treatment regulation (YKTY),

5- Ministry of Health Publications,

6- Administrations and Organizations,

7- Occupational Health and Safety,

8- Guidance for Business Managers,

9- Management of Healthcare Institutions,

10- Quality Standards in Health. 
It is stated that only $34.8 \%$ of our health executives read "articles" on health or general management where only $17,8 \%$ of them read "periodicals. However, the "periodicals" followed by executives were limited to those corporate publications of their institutions, magazines, brochures, in other words, no sign of academic periodicals have been detected. Therefore, it is thought-provoking that the executive group does not have Literacy on Health Information, on health or general management.

In a study conducted by Balc1 et al. [14], on the general characteristics of health professionals in Kayseri; nearly $60 \%$ of the managers expressed their wishes about using computers, and their deficiencies in computer literacy were determined.

In our study, however, it was found out that only $65.9 \%$ of the community health managers in Diyarbakır used computers.

Considering the health information systems in the rapidly changing health sector, such alow rate of computer literacy, as $65.9 \%$ throughout the managers, while it is the most ideal means of accessing information, has revealed that it should be among the issues that should be emphasized for professional health managers. Therefore, in our study, the deficiencies of our managers about computer literacy were determined.

Moreover, no statistical significance was found out in the comparisons among different level managerial groups, or different managerial professions in terms of their; computer literacy (Table 3), book reading habits on health or general management (Table 4), reading articles on health or general management (Table 5); following publications on health or general management (Table 6), whether or not they did have a post-graduate degree on health or general management (Table 7). It is thoughtprovoking in terms of professional health management and hence the future of HTP that Literacy on Health Information, which should be a sine qua non of professional health management, has not been identified in favor of a different group among managerial groups.

Parallel to the results obtained from our post-study field impressions and the comparisons that have been tried to be demonstrated above, Non-Literacy of health managers on Health Information, prior to the restructuring of provincial healthcare services (November 27, 2017), and the fact that the former executives who gave rise to this situation also are in charge in the new provincial health structure, will negatively affect the success of the province's healthcare services. In other words, not having Literacy on Health Information will have a negative impact on corporate governance.

Despite the 16-year experience of the Health Transformation Program (HTP) implemented by the Ministry of Health throughout the province, this study reveals that even though Literacy on Health Information is considered as a sine qua non in professional health management, the level of Literacy on Health Information among current professionals is still insufficient. This should be immediately addressed by the Ministry of Health and its related units.

With a few items, results and recommendations may be summed up as;

1- Only a quarter of the managers in the health sector are women. Managerial roles of females should be increased.

2- It is essential that the Ministry of Health should encourage receiving postgraduate education on both general management and health services management. Protocols can be signed with health management departments at the existing universities and the Ministry of Health to encourage postgraduate or Ph.D. education.

3- In order to encourage the follow up of current periodicals on general and/or Health Care Management among provincial health managers, hence supporting Literacy on Health Information, these 
publications should be increased in terms of quality and quantity, and they should be delivered regularly monthly or every 2 months, to be read by the Ministry of Health.

4- Recognition that professional health management is mandatory for the achievement of HTP, and providing employment opportunities for graduates of health management departments of universities will pave the way for professionalism in the health sector.

5- In service training on the Principles of Management, Management of Health Care Sector should be organized by the Provincial Directorates of Health for existing managers of health via signing protocols with the health or general management departments of universities, and these trainings should be continued periodically during the month.

6- It is thought-provoking that the level of computer literacy among healthcare managers is quite low despite the fact that the most important tool that will enable the managers to reach Literacy on Health Information is the computer.

7- In order to increase the level of academic literacy on health or general management, current articles can be delivered to the corporate e-mail addresses of the healthcare managers by the Ministry of Health, current managerial books can be listed by the Ministry, with the purpose to encourage the managers towards buying and reading them, or it should be exercised on whether it is possible to read these books as pdf on the Ministry website.

8- The importance of Literacy on Health Information has frequently been reviewed in academic studies within the scope of health care service recipients and the nurse-physician who provides the service, etc. But this situation has always been ignored by executive health personnel. The main problem should be to eliminate the theoretical knowledge deficiency of the people involved in the current managerial positions.

\section{Ethical considerations}

Ethics committee approval was obtained from Dicle University Non-Interventional ethics committee for the study (Certificate authorization number, 385 dated 23/10/15).

\section{Acknowledgment}

Informed consent was obtained from all individual participants included in the study. The authors declare that they have no conflict of interest.

The compliance to the Research and Publication Ethics: This study was conducted in accordance with the rules of research and publication ethics.

\section{References}

[1] Çopurlar C.K., Kartal M., "Sağlık Okuryazarlığı Nedir? Nasıl Değerlendirilir? Neden Önemli?”, Turkish Journal of Family Medicine and Primary Care, 10(1), 42-47, 2016.

[2] Belek, İ., Sağlıkta Dönüşüm: Halkın Sağlığına Emperyalist Saldırı, İstanbul, 2008.

[3] Tengilimoğlu, D, Işık, O. , Akbolat, M., Sağlık Işsletmeleri Yönetimi, Nobel Yayınları, Ankara, 2009. 
[4] Sağl1kta Dönüşüm Programı, T. C. Sağl1k Bakanlığı Yayınları, Ankara, 2010. www.saglik.gov.tr. (accessed May,11,2018).

[5] Eracar R., Avrupa Birliği Uyum Sürecinde Türkiye'de Sağlıkta Dönüşüm Programının Hastalar Tarafından Değerlendirilmesi: Ankara İli Özel İki Hastane Uygulaması, Master Thesis, Ankara, 2013.

[6] Akdağ, R. ,Türkiye Sağllkta Dönüşüm Programı, Republic of Turkey, Ministry of Health, Ankara, www.saglik.gov.tr. (accessed May 11, 2018)

[7] Bulut, D. ve İşman, Ç., "Muğla İli Sağlık Yöneticilerinde Kişisel Değer Analizi”, Hacettepe Sağllk İdaresi Dergisi, 7(3), 277-293, 2004.

[8] Hayran, O. ,Sur, H., Sağlık Hizmetleri El Kitabı (1. Baskı), Nobel Tıp Kitapevi, İstanbul, 1998.

[9] Sur, H., Dünyada ve Türkiye'de Sağlık Yöneticiliği, 2009, www.merih.net/m1/0mngmt.htm. (accessed Jan.05, 2018)

[10] Kurt M.E., Sağlık Hizmetleri Yöneticilerinin Yönetim Eğtim İhtiyaçlarının Belirlenmesi; Diyarbakır Örneği, PhD Thesis, Dicle Üniversitesi Sağlık Bilimleri Enstitüsü, Diyarbakır, 2016.

[11] Öztürk A.,Tolga Y., şenol V., Günay O., "Kayseri İlinde Görev Yapan Sağlık İdarecilerinin Tükenmişlik Düzeylerinin Değerlendirilmesi”, Erciyes Medical Journal, 30(2), 92-99, 2008.

[12] Güneş G.,Çolaklar H.,Aras B.,Turan A. Tıp Okuryazarlığı ile ilgili Yaklaşımlar,ÜNAK 2013 Konferans1: Bilgi Sistemleri, Platformlar, Mimariler ve Teknolojiler, September, Marmara University, İstanbul, 2013.

[13] Karsavuran S., Sağl1k Sektöründe Mobbing: Hastane Yöneticileri Üzerinde Bir Uygulama, Mustafa Kemal Üniversitesi Sosyal Bilimler Enstitüsü Dergisi; 11 (26), 271-296, 2014.

[14] Balcı E.,Çakıl E.,Dudak AH.,Gün İ.,Çetinkaya F.Günay O. “Kayseri Illi’nde Görev Yapan Sağlık Yöneticilerinin Genel Özellikleri Ve Uygulamada Karşılaştıkları Sorunlar”, Journal Of Health Sciences, 20(3), 174-183, 2011. 